\title{
MedienPädagogik
}

www. medienpaed.com

Zeitschrift für

Theorie und Praxis

der Medienbildung

ISSN 1424-3636

Themenheft Nr. 24: Educational Media Ecologies

\section{Mobile Learning \\ Structures, Concepts and Practices of the British and German Mobile Learning Discussion from a Media Education Perspective}

Judith Seipold

\begin{abstract}
As a scientific field within media education and educational sciences the research on and the practical implementation of mobile learning is evolving. An analysis of the predominantly British scientific process of the mobile learning discussion - to which this paper refers to (Seipold 2012) - is opening the view to a taxonomy of this discussion, its contexts, reference points, perspectives and conceptual focal points, as well as to success stories and challenges that are related to the implementation of mobile learning in formalised learning contexts, such as schools.
\end{abstract}

\section{Introduction}

In formalised learning contexts such as school, mobile learning is realised in multiple ways. For example, mobile technologies are used as replacement for analogue media and technologies. The use of different functionalities of mobile devices are widening the learners' scopes of action. In addition, the use of devices that is dependent on specific situations and the devices' functionalities support learners in constructing user-generated contexts and so forth. Whilst research on mobile learning is dedicated to activity-oriented use in practice, and the theoretical engagement with this issue considers mainly constructivist approaches to learning, the scientific process of the mobile learning discussion is hardly reviewed and structured yet.

The following taxonomy that appears in relation to the scientific process of the British and partly the German mobile learning discourse and that is related to media education and educational sciences (see e.g. Seipold 2012b) is incomplete, but it refers to findings, insights and consequences for the development of theories, for practical research and for the implementation of mobile learning in formalised school-related learning contexts. The British mobile learning discussion serves as an initial point for this analysis, because in the U.K. mobile learning is researched systematically, and with a view to formalised learning contexts for almost 15 years (for an overview of some of the early European pioneer projects in mobile learning see below as well as Seipold 2012b). In the following, an overview of contexts, reference points, perspectives and theoretical foci of the current 
discussion is provided. This overview originates from the British mobile learning discussion, from successful use of mobile technologies in school contexts, and from resolving challenges that occur during the implementation of learning with mobile technologies in schools. As a start, a review of the basis of research on mobile learning, including defining mobile learning and its goals is provided.

\section{Mobile Learning is ...}

The intention to describe mobile learning according to current literature leads to a list of terms and characteristics (Kukulska-Hulme 2005). Mobile learning is characterised as being «spontaneous, personal informal, contextual, portable, ubiquitous, and pervasive» (ibid., 2). «lt can be informal unobtrusive and disruptive» (Kukulska-Hulme and Traxler 2005, 42), as well as «ambient» (Kukulska-Hulme 2005, 2). It is "highly situated, personal, collaborative and long term; in other words, truly learner-centred learning» (Naismith et al. 2004, 36). Mobile technology allows immediate and ubiquitous interaction (Kukulska-Hulme 2005). By doing so, mobile technology enables learners to learn beyond "schooling practices, in which what is being taught is abstracted from its naturalistic (ecological) space where it has real function with the world» (Pachler 2010, 154). Despite attempts to define mobile learning as exactly as possible there does not currently exist a definition of mobile learning that is generally accepted. In fact different definitions point to different fields that mobile learning comes from and refers to, as well as to the disciplines that are related to mobile learning. Also, such characterizations show the current state of research, the current developments within the mobile learning field, and the specific rationales for the legitimization of mobile learning. This results in the description of mobile learning as, for example, mobility of contexts, as mobility between contexts, as mobility of learning processes, and it results in definitions which base on learning theories that focus mobility, efficiency, technology, that consider social structures and infrastructure, and that describe mobility as mobility of expectations (Pachler 2010; Seipold 2012b; Sharples, Taylor, and Vavoula 2005; Traxler 2009).

\section{Mobile learning aims ...}

Accordingly, the research intentions of media education and educational sciences should be evaluated. The mobile learning discussion indicates that mobile learning can be a reason to have a look at technology, learners, teachers, contexts, concepts, learning contents, teaching design / didactics, ways of learning, places and times for learning, social developments, the educational system, and so forth. Authors write about learner centred learning (Luckin et al. 2010; Naismith et al. 2004; Traxler 2009), opening of schools for learners' everyday life (Pachler, Bachmair, and Cook 2010), learning during leisure time (Naismith et al. 2004; Sharples, Taylor, 
and Vavoula 2005), learning as filler (Sharples, Arnedillo-Sánchez, Milrad, and Vavoula 2007, 3), about «new» learning (Naismith et al. 2004, 36), about the shift of power levels in relation to access and distribution of knowledge (Luckin et al. 2010), as well as about the democratisation of learning (ibid.). As a result, mobile learning sometimes seems to be a welcome opportunity to question education, formation (Bildung), pedagogy, the educational system as well as current concepts of teaching and learning. This might be a reason why protagonists of the mobile learning discussion sometimes seem to be paradigmatic with their statements and claims.

\section{A taxonomy of the mobile learning discussion examined from a media education and educational sciences perspective}

The existing scientific process of the British and German speaking mobile learning discussion can be reviewed to understand the discourse that shape mobile learning as an issue and as a research field, and to deduce results that scrutinise the current state of the mobile learning discussion critically. Also, by providing a taxonomy, it is possible to justify the foundation of mobile learning research (i.e. contexts of the discussion), to comprehend the discussion's self-created basis of legitimation (i.e. argumentative patterns constituting the discussion), and to frame the structure of the discussion (for details see Seipold 2012b).

\section{Contexts of the mobile learning discussion}

As an interdisciplinary field the research on mobile learning is connected to disciplines, fields and topics such as technology enhanced learning, media didactics and sociology. Research on media use in everyday life, as well as e-learning, shape mobile learning and serve as the contexts of the discussion. Key players in the discussion who define topics, theories, models and concepts are located in the UK. There, big and costly projects dealing with practice and action research were realised at the beginning of the 21 st century. Such projects provide the basis for assumptions which are now commonly accepted within the mobile learning community.

- People, institutions, conferences: For a long time within a central European context, the research based in the UK was ground-breaking for the research on mobile learning in school contexts. Key players of the British mobile learning discussion focussed on shaping the field of mobile learning with views on media education and educational sciences, and related disciplines. Efforts were made to define and develop mobile learning on a theoretical and conceptual level, as well as implement it. Indicators of the continuation of mobile learning are the interest of research institutions in this topic, as well as the growing number of national and international conferences, and the foundation of associations, 
institutions and special interest groups that are engaging in mobile learning (for details see Pachler et al. 2010; Seipold 2012b).

- Practice oriented basic research: On the basis of large-scale projects such as the Palm Education Pioneers project (http://palmgrants.scri.com), MOBILearn (http://www.mobilearn.org), m-learning project (www.mlearning. org/archive/index.html) or HandLeR (Handheld Learning Resource; www.eee. bham.ac.uk/handler) possibilities for practice were evaluated. Acceptance amongst teachers, learners and decision makers was appraised and options of opportunities in school, as well as the active, networking and constructive role of learners were explored. Questions related to the increase of learning efficiency and self-development of learners in school contexts was worked on; and the options to personalise technologies, ownership of the devices as well as the acknowledgement of applications that are used in everyday life contexts were analysed (for details, see Seipold 2012b).

- E-Learning: E-Learning is often referred to as the «original» reference discipline of mobile learning (Auer, Edwards, and Garbi Zutin 2011; de Witt et al. 2011; del Mundo 2009; Ernst 2008; Sharples 2007; Traxler 2005; Traxler 2009). Besides making learning contents available via digital technologies and the continuation of desktop-centred e-learning, e-learning is relevant for mobile learning because new opportunities for the autonomy of mobile learning are originating from the dissociation of mobile learning from e-learning. The possibility to personalise technologies and learning with mobile technologies is often given as an example (Benedek 2007).

- Sociology: In Germany, Austria and parts of Switzerland, sociological research on the use of mobile devices, mobility and societal implications of mobile communication has to be seen as basic research that considers the media use in everyday life. By doing so, Sociology provided a basis at the beginning of the 00s already which allows to connect mobile learning to the use of mobile technologies in private and public spaces and to discuss consequences resulting from this use (Glotz et al. 2006).

- Media use in everyday life: From the perspective of an ecological approach of mobile learning it is important to gain an understanding of the structural conditions of society and technology (Bachmair 2009a; Bachmair 2010; Pachler et al 2010) as well as understand how people are dealing with convergent technologies in their everyday life: Users cultivate (basing upon their agency) cultural practices, which can be described as routines, and which are basing on activities such as the organisation of their everyday life and social relationships. Such routines must be viewed in the context of specific situations. Examples of these routines might be the exchange of information or the ritualised communication amongst peers, as well as learning or the 
experienced organisation of everyday life; also expertise and competences are exercised in relation to cultural practices. These practices are important for the implementation of learning with mobile technologies and for learning in general, because they can be considered central to the background of the learners' everyday life, as subjectively meaningful and as meaningfully cultivated and positioned. Thus, mobile learning is effective in reaching learners that are more challenging to reach in traditional school contexts (see Joint Information Systems Committee [JISC] 2008; Pachler, at al. 2010).

\section{Argumentative reference points of the mobile learning discussion}

Learners, schools, educational systems, learning processes and societal conditions (or, seen from a socio-cultural ecology perspective, an interplay of these components) are serving as reference points and foci of research within the mobile learning discourse (see Figure 1). However, it is the learner who is considered as standing in the centre of his or her learning activities and his or her structures. Claims that are articulated in this relation are important markers that point to what learning - not just mobile learning - should be in the background of our information and knowledge society, and which role people, institutions, resources and contexts that are involved in learning and the learning process can and should play (Seipold 2012b; Seipold 2011a; Seipold 2011b):

- Technologies: At the beginning of the discussion, mobile learning was strongly focussed on technologies, which were considered enablers for personalised and collaborative learning. Besides, technologies are - in a less technology centred viewpoint - understood as being infrastructure, tool and resource for learning and meaning-making.

- School system and school: Learning by using mobile technologies should result in a school system that is open for resources from the learners' everyday life, for example, their knowledge, expertise, information, interests, practices and so on. These resources should be integrated into classes and learning. By doing so, schools will become innovative, enabling and supporting the independence and democratisation of learning and learners.

- Learners: Learners are entitled to freedom, which allows them to learn in selfresponsible, creative, formative, competent, networked, sustainable and lifelong ways. This freedom implicates responsibility that can finally result into negative results, for example, when frameworks are missing which provide orientation and classification to learners to transform their subjectively shaped learning into objectively shaped school learning.

- Learning process: Because learning is no longer teacher centred, learners are entering learning processes that are characterised by discourse related, communicative, equal, collaborative, networked and enabling structures. 
Thus, learners have equal rights in their learning process. Hierarchies shall be removed and equalised as far as it helps learners.

- Social conditions: Research on mobile learning often does not cover all of the above aspects in a connected manner, even though technological developments as well as appropriation of structures and cultural practices cannot be separated from their specific social conditions. Cultural practices can be characterised as unstable, shaped by different cultures, and as subjectively realised ways of experiencing the world around us. These practices are consumer-orientated, globalised, and community orientated. This must be considered when working with people from different social backgrounds, for example.

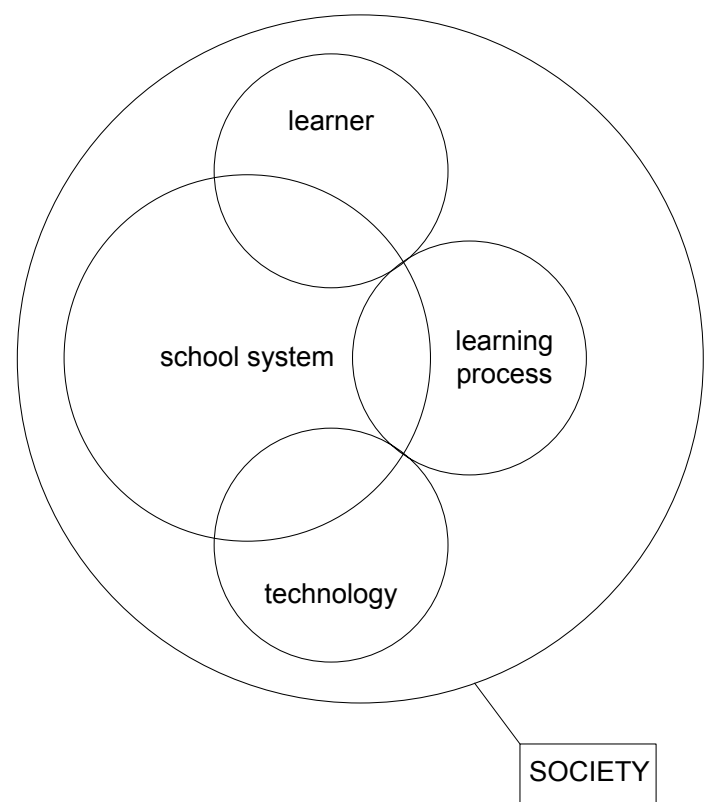

Figure 1: Argumentative reference points in the mobile learning discussion (Seipold 2012b).

Argumentative patterns shaped by people involved in the mobile learning discussion provide the basis for the legitimization of the mobile learning discussion

When looking at the argumentative patterns that are relevant for the mobile learning discussion of the last thirteen years (see Figure 2) it appears that on one hand the implementation of mobile technologies in formalised learning contexts, such as schools, does not work seamlessly. However, on the other hand, mobile learning is not limited to a technology-centred view but it encompasses didactic aspects, as well as learning that is evolving. These patterns provide a legitimization basis for mobile learning by referring to different dimensions: 


\section{Practices constituting the scientific process}
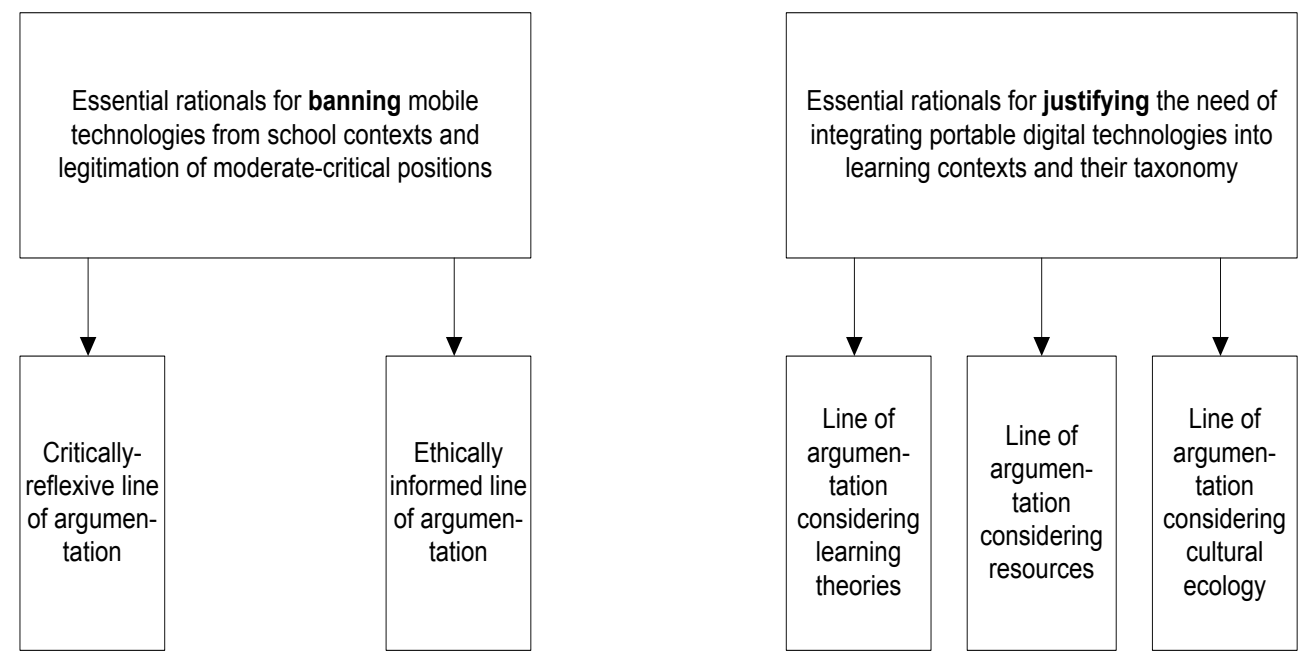

Figure 2: Argumentative patterns related to the constitution of the scientific process of the mobile learning discussion (Seipold 2012a).

Those who oppose mobile learning initially argued for a ban of mobile technologies in school contexts. This strict position was gradually replaced by a moderate position that can be described as critically-reflexive and empowering. In this connection, often an ethical line of discussion appears. The advocates of mobile learning refer to one line of argumentation that is related to learning theories and to one line that argues in regards to resources and socio-cultural ecology. Learners and learning processes, as well as an understanding of media use, which is considered to be subjectively meaningful to users / learners is central within this approach. These subjectively shaped aspects must be linked to objective frameworks and guidelines of formalised school learning - or vice versa (Seipold 2012b):

- Critically-reflexive line of argumentation: This line of discussion primarily results from the first affective discussions around the use of mobile technologies in and out of school contexts. It is typically a reaction to the concept of mobile technology as a problem. Initially mobile technology was a taboo subject in classrooms or on school property, however proponents developed protection of minor policies and showed positive use of mobile technology in working groups and extracurricular activities (Alfred-Teves-Schule 2008; medienbewusst.de kinder. medien. kompetenz 2009; Medienpädagogischer Forschungsverbund Südwest [mpfs] 2013). Such activities and offers favour a practical approach 
with the goal of enabling learners to responsibly use technology. Also, these activities contribute to regulated acceptance of mobile technologies in school contexts and in everyday life.

- Ethically informed line of argumentation: The ethical dimensions within the mobile learning discussion are also related to the research on mobile learning (Wishart 2010; Wishart 2011). This area is cultivated with the intent to protect personal rights of people engaged in research projects, and also questions concerning copyrights and issues, such as rights to personal photographs, sounds, learning materials, etc. are considered. Here, one of the central approaches is to consider such ethical standards in advance and to work these rules out collaboratively (Traxler 2010).

- Learning theories-centred line of argumentation: Learner centring, interaction, flexibility and sustainability in the learning process are the focal points in the line of argumentation that is related to learning theories. Useful in this context are possibilities of personalisation of devices that allow the adaptation to the learner's specific needs (Naismith et al. 2004) and expertise. In this regard there is not a primary focus on teacher centred learning, examination centring or assessment. Thus, learning becomes more and more activity centred and free from traditional forms of transfer of knowledge.

- Resource-centred line of argumentation: The availability of resources as well as infrastructural equality in the learning process and the educational system are issues that have relevance for those debating the resource-centred line of argumentation. Basis of the issues regarding the availability of resources in general and the concept of providing equipment top-down (see below). This is because by providing resources such as mobile devices to learners, it is possible to establish an equality of opportunity, and social disadvantages related to equipment can be balanced (Benedek 2007).

- Cultural ecology-centred line of argumentation: Within this line of argumentation, technologies are initially examined based on the use of media in everyday life, and are seen as tools for learners to organise their everyday life. But, supporters of this line of argumentation are losing their key position within the argumentation complex: Technologies are taken up in technological and social structures that are surrounding learners and are designed and organised by learners. This is because mobile technologies are considered to be resources within the process of appropriation. These resources can be used for access to and production of a variety of activities, structures, contents and knowledge. By handling the mobile devices, learners cultivate agency and cultural practices which can be taken up by school and which can serve as "conversational thread between informal learning in everyday life and curricular learning» (Bachmair 2009b, 1). 


\section{Structure of the scientific process of the mobile learning discussion}

Besides contexts, argumentative reference points and argumentative patterns, it is finally a course that is structured on two levels by phases and development lines which result from the systematization of the scientific process of the mobile learning discussion. The phases give the scientific process a chronological sequence (horizontal). The development lines structure the scientific process vertically and can be described as topics (see Figure 3). But these topics cannot be limited to single phases; topics form phases at a certain time more or less intensively, and by doing characterize certain phases.

- Phase 1 Exploration stands for exploring the research field with a focus on technology-centring, learner-centring and content-centring when implementing mobile technologies and applications in school contexts. The attempt to integrate mobile technologies as resources and as enablers of mobility, connectivity and activity in school lessons, thus adding technologies onto already existing structures and to further integrate them into curriculum and learning processes (top-down approach) characterize this phase. The development of applications (software) for learning and the aim to make learning contents available that are developed for mobile technologies are also part of this phase and are rooted in the tradition of technology enhanced learning. In this regard, central and characteristic of the early phase of mobile learning research is the question of how to integrate school learning into the learners' everyday life. Mobility and efficiency are central reference points. Also within this phase The personalisation of technologies, as well as particular learning theories that can be considered as being basic for learning with mobile technologies, (Naismith et al. 2004) gain relevance. Also, basic research is part of this first phase: Theses and assumptions are formulated which try to provide a basic understanding of how mobile technologies can and are used for learning.

- Phase 2 Application is shaped by the use of models to describe learning processes and by the construction of theories. Focus is on the learners' activities during the learning process, and on learning that is understood as «situated activity» and "participation in social practice» (Lave and Wenger 1991, 35). In this regard, hardware and software fade into the background; a collaborative, conversation and discourse oriented Engagement in learning and learning resources during the learning process gains more relevance. Accordingly, the leading theoretical and conceptual frameworks cover models that help in understanding collaboration, activity and conversation in the processes of learning. Also, these models are used as frameworks for planning and for the analysis of mobile learning. This is especially true for the Activity Theory (Engeström 2001; Engeström 2005) and the Conversational Framework (Laurillard 2002; Laurillard 2007). Sharples, Taylor, and Vavoula (2010) have, 
based on these two models, developed initial attempts of a theory of mobile learning.

- Phase 3 Development of models is shaped by three development lines: the development line of proximity to everyday life draws a line from protectionism and banning of mobile phones to a critical media formation (Medienbildung) and school learning that also considers resources from the learners' everyday life; the development line of the ecology models considers components in the learning process that are involved in a mutual relationship; the development line of User and Learner Generated Contexts deals with learning places and learning contexts that are constructed by users or learners, and can be described as spaces for activity and creation. The tendency that becomes apparent within Phase 3 is to understand that learners are surrounded by their specific social, cultural and economic contexts, in which they are actively engaged in media use while creating, appropriating and constructing as part of formal learning. To get a hold of these complex dynamics in which learners are embedded and that they are constructing, some authors refer to the term «ecology» (Luckin et al. 2010; Pachler, et al. 2010; Sharples, et al. 2010). One current model that explicitly refers to mobile learning is the model of «Socio-Cultural Ecology of Mobile Learning» (Pachler, et al. 2010; see below also). This model covers areas that describe teaching as the provision of contents and teaching units, and also as discussion oriented and contexts and contents generating process of appropriation done by learners by referring to their agency, cultural practices and the structures by which learners are surrounded and which learners are constructing (see ibid. and below).
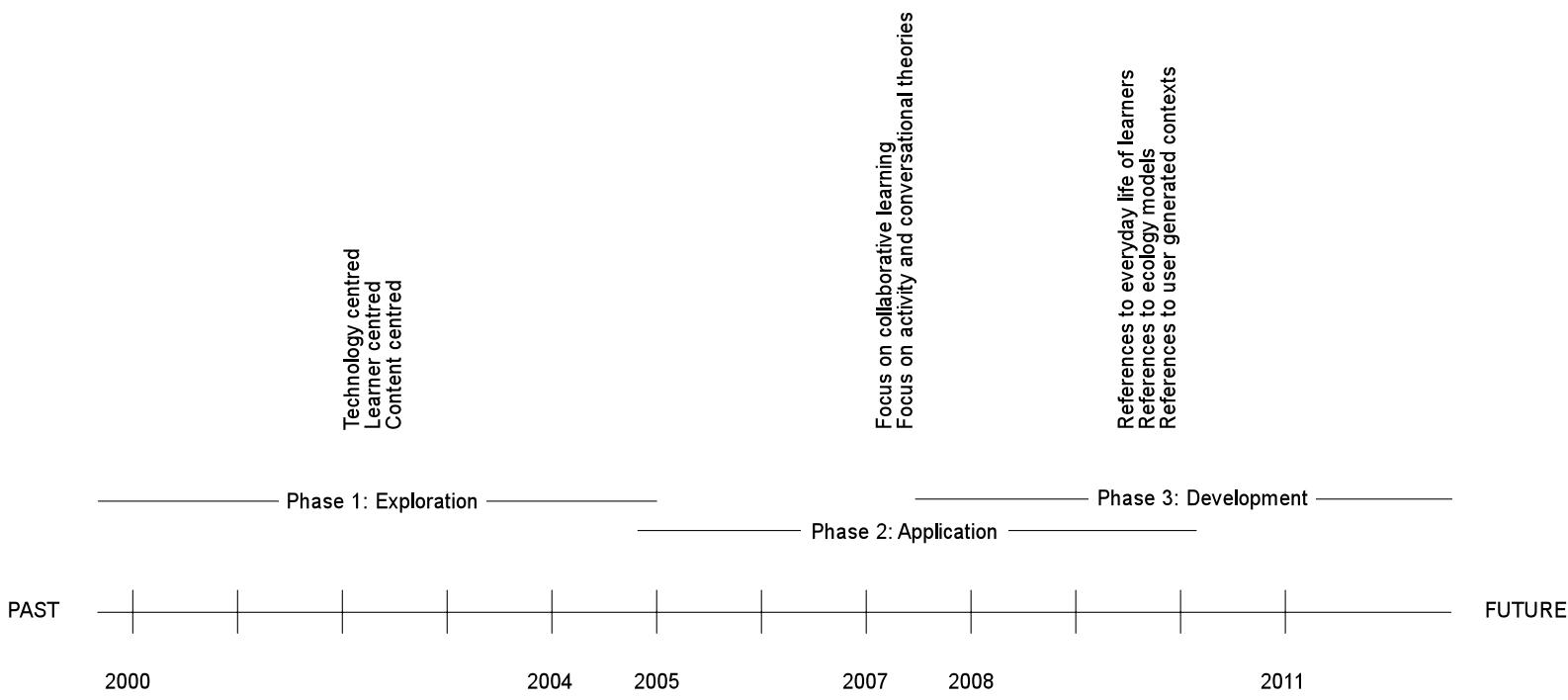

Figure 3: Structure of the scientific process with its phases and development lines (Seipold 2011b). 


\section{Prominent theories, concepts and models of the mobile learning discussion}

Just a few theories, concepts and models that are used to explore, to analyse and to plan mobile learning are central in the current mobile learning discussion, for example, Engeström's Activity Theory $(2001 ; 2005)$ and Laurillard's Conversational Framework (2002; 2007) as well as Sharples et al.'s (2010) Theory of Mobile Learning. Whilst Engeström and Laurillard put a focus on activity and conversation during the learning process, Sharples and colleagues want to make a model available that allows researchers and practitioners to access mobile learning as phenomenon and activity on several levels. In addition, there exist concepts such as Lave and Wenger's Communities of Practice (1991), their concept of situated learning and the «legitimate peripheral participation» (ibid., 31) as well as Vygotsky's ([1930] 1978) Zone of Proximal Development (ZPD) which are used to understand mobile learning. Even though these models are already successfully used for the description and analysis of single processes and phenomena of mobile learning the theory of mobile learning is still to be formulated.

The learner in the centre: theoretical an conceptual framework of a SocioCultural Ecology of Mobile Learning

The London Mobile Learning Group (LMLG) does not make a claim to develop such a theory of mobile learning, however, members of the LMLG do try to provide with their Socio-Cultural Ecology of Mobile Learning (Pachler et al. 2010) a framework for the analysis of mobile learning that does not only highlight one specific aspect of mobile learning practice, but that also includes socio-cultural and technological structures, agency of learners and their cultural practices as cornerstones. These cornerstones are embedded in the so-called «Mobile Complex» (ibid.), that is to be understood as social, cultural and technological changes and dynamics. By doing so, the learners' lifeworld is an argumentative starting point for the appropriation of cultural resources (e.g. media) via agency and cultural practices within given or self-created structures. Appropriation (or learning) is understood as a process of the producing and receiving engagement when using mobile technologies and is subjectively meaningful. In the course of this process learners engage in meaning-making. Both, appropriation and meaning-making, is defined as situated, contextualised and subjectively shaped. Accordingly learning - if understood as appropriation - can be described as a process of meaning-making within the arrangement of social and technological structures, cultural practices and agency (ibid, 156). For the mobile learning discussion the introduction of such a model means a systematic extension of the field. This extension has to do not only with the aspects mentioned above, but also with the learners' subjectively meaningful appropriation and meaning-making with the aim to position oneself (e.g. in relation to everyday life or school contexts). This, finally, offers prospects for education and formation (Bildung). 


\section{"Learner Generated Contexts» as resource, construction process and space of possibility}

Against the background of the above, the concept of User Generated Contexts or Learner Generated Contexts gains importance. The concept is used to describe and understand the situational attitude of appropriation, which varies depending on place, time and availability of cultural resources, and it aims at the same time appropriation to be seen within dynamic, fluid and unstable structures (Cook 2010). Therefore, the context concept is a micro-view of the Mobile Complex (Cook, Pachler, and Bachmair 2011; Cook, Pachler, and Bradley 2008) as well as an attempt of systematisation and operationalization. By referring to the context concept, formal and informal (mobile) learning situations and processes become describable, comprehensible, reconstructible and thus plannable (Brown 2010) for learning contexts and lessons. Seen from the perspective of the mobile learning discussion the concept of learner-generated contexts has relevance because of the following reasons:

- The context concept moves the focus away from user-generated contents (UGC), which are produced within contexts (Luckin et al.,2010), and thus away from the idea learning tools or pre-set learning contents would be central for the learning process.

- Learning materials such as school books are not the only resources providing learning contents; also agency of learners, technologies, structures, networks, contents and so on gain importance, whether they are from the learners' everyday life or from school and learning contexts.

- On the way towards the development of a mobile learning theory it appears to be important to put a focus on contexts because, as new cultural products, (Bachmair 2010, 24) they are constructed by learners. In these self-produced contexts, the learners' agency, cultural practices, as well as their expertise, aesthetics, concepts of learning, aspects of identity, become apparent.

- The context concept provides links to current developments in mass communication as well as a contemporary understanding of learning as meaningmaking in formalised and informal structures, because both move away from the idea of users/learners being consumers of pre-given contents towards an idea of users/learners as producers of self-chosen and self-created contents (The Learner Generated Contexts Group 2008).

- Because contexts can be situationally constructed anytime, anyplace, school and classroom lose their central position as only place for learning in the formalised learning process; other places or spaces - be it a swimming pool or a chat room - become relevant places for learning.

- Therefore, the context concept reveals the learners' everyday life to informal learning and allows researchers to construct links between informal and formal contexts and activities, and to frame them systematically. 
- Within contexts, users/learners act in a flexible manner and are able to adjust resources (including structures, agency and cultural practices) to the demands and conditions of contexts.

\section{Practice of mobile learning in school contexts}

A short presentation of consequences will be given below that result from the relation between the implementation of mobile learning in schools, the demands from theory and the use of mobile technologies in everyday life. These consequences address aspects of teaching design, as well as areas that can be considered as being problematic, challenging, or successful. Also, it is possible to make statements related to different approaches of the implementation of mobile leaning in school, related to different degrees of opening of lessons towards the learners' everyday life, and related to dialectics that result from the contrast between the theory led mobile learning discussion and mobile learning practice. However, mobile learning has real innovation potential. It appears in a small scale only and often remains unnoticed, but it provides links to support personalised learning and to re-think traditional practices of meaning-making and learning (Pachler, Bachmair and Cook 2010; Seipold 2012b).

\section{Three approaches to implement mobile learning in school-based learning practice} Three of the most common ways to implement mobile learning in formalised teaching and learning contexts are the «top-down approach» (technologies are made available via the institution and are set-up onto already existing structures), the «bottom-up approach» (teachers and learners rely on technologies and agency from everyday life) and the "demand-oriented approach» (formerly called the "affordance approach»; technologies and agency are situationally used) (see Figure 4 as well as Seipold 2012b; Seipold 2011a). Each of these different ways of implementation exemplify how to open school and lessons towards the learners' everyday life, their agency and their cultural practices (see Figure 5): The more learners are allowed to use their resources and cultural practices from everyday life, the more school opens itself towards the learners' everyday life and their preferred approaches to learning (whether they are teacher-centred or constructivist):

- Top-down approach: Often mobile devices are implemented into learning contexts from top to bottom, which means the devices are set-up in relation to already existing teaching and learning structures. This happens within big projects that have large budgets, for example. In such projects, whole grades, years or even schools are provided with mobile devices such as PDAs. On the one hand, this approach entails strong regulation; learners find themselves in pre-constructed structures and scopes of action. On the other hand, learners are provided with the necessary technology, infrastructure and resources that 


\section{Three approaches to implement mobile technologies into formalised learning contexts}

\author{
Top-down approach \\ (,from the top to the bottom")
}

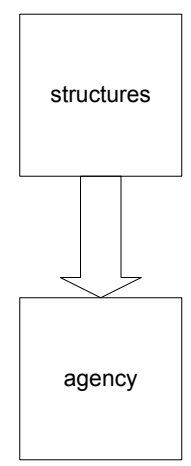

Put structures on already existing structures

Integration of school learning into learners' everyday-lives

Focus: structures, equal opportunities

\author{
Bottom-up approach \\ ("from the bottom to the top")
}

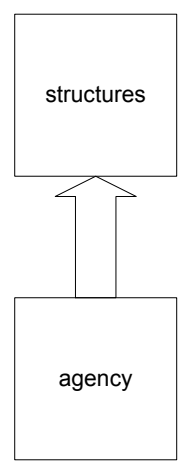

Use of resources available Integration of learners' everyday-lives into school structures

Focus: agency, expertises
Affordance approach (demand-oriented use)

Demand-oriented use of technologies, resources and agency Focus: balance of different components

Figure 4: Three approaches to implement mobile technologies into formalised learning contexts (Seipold 2012a).

provide the basis for equal opportunities within the learning process, as well as for personalised and collaborative learning. These aspects may be relevant for learners who are disadvantaged on an infrastructural level, as well as for those characterized as weak learners. Both groups could find support through the top-down approach that is characterised by the provision of an infrastructure for learning.

- Bottom-up approach: The bottom-up approach takes available resources, such as devices and knowhow of learners and teachers into account. This saves cost because devices do not need to be supplied. In addition, learners are confident with their devices and can revert to their routines, competences and knowledge when using them. This approach targets all learners equally as it addresses topics, interests, competencies, expertise, and knowledge that are based in the learners' everyday life, and it opens school to all of these aspects. However, these resources have to be moderated by teachers and must be integrated into categories of school. With a view to technology, an approach like «Bring Your Own Device» (BYOD) possibly brings infrastructural challenges. However, these challenges could be seen as an opportunity for peer-teaching or collaborative learning, for example. 
- Demand-oriented approach: The demand-orientated use of mobile technologies is the option that is closest to the everyday use of mobile technologies. This is because the devices, applications and practices are used only when users consider them necessary or helpful, or when teachers apply them selectively and explicitly as teaching and learning tools. Mobile use within this scenario is often related to the use of Interactive Whiteboards or platform solutions, such as Moodle or Mahara. Such arrangements are often very complex, and in order to guarantee the seamless use of these technologies in class, it is necessary to guarantee stable and sustainable infrastructures that are accessible to learners also from outside school (e.g. from home or on the go). Apart from this the demand-oriented strategy allows the school to be open to media use in everyday life, as appropriate, and allows the design of lessons by referring to instructional or communicative and discursive learning, alone or in groups. Also, it provides the opportunity to choose learning materials and contents provided by the school or to refer to resources from everyday life.

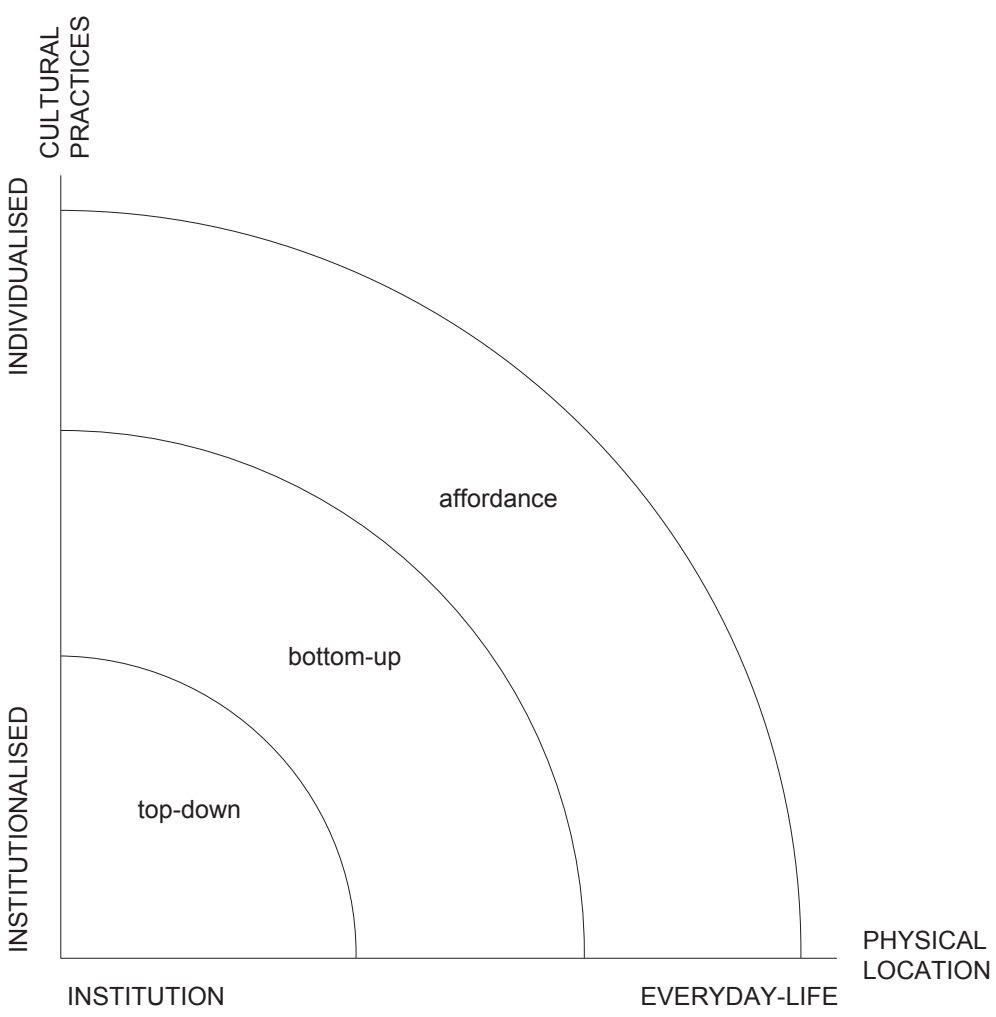

Figure 5: Opening of lessons with reference to three ways of implementing mobile learning in schools (German version in Seipold 2013). 


\section{Opening of school and lessons}

One of the consequences deriving from these three approaches of the implementation of mobile learning relates to the opening of school and lessons. Within formalised contexts, this would mean that lessons range from strongly regulated learning and a focus on school as the place for learning to the individually shaped appropriation mechanisms that involve the opening of lessons towards the learners' everyday life (see Figure 5). Here it becomes obvious that the use of mobile technologies in school does not inevitably mean an opening of school or lessons. This, as well as the question of the implementation of mobile learning, and the contradictions in mobile learning practices (see below) must be considered when planning mobile learning.

\section{Contradictions and breaches}

Mobile learning in school practice can foster contradictions, and by doing so can cause difficulties rather than solution and «seamless transitions» (ArnedilloSánchez 2008, 77) between different contexts (see Figure 6).

\section{Use of mobile technologies in everyday-life}

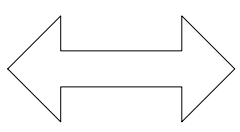

\section{Subjective}

Ephemeral streams

Subjective meanings

Momentariness

Multimodality

Informal

Ad hoc / affective / intuitive use

$$
\text { Everyday-life }
$$

De-construction

\section{Use of mobile \\ technologies in \\ formalised learning \\ contexts}

Objective

Sustainable use

Collaboratively agreed meanings

Sustainability

Monomodality

Formal

Supervised / controlled / refelcted use

Institution

Instruction

Figure 6: Contradictions in the use of mobile technologies in schools with focus on the duality of everyday life - school (German version in Seipold 2013).

Basically these challenges result from a «recontextualisation» of mobile devices and their functionalities when they are transferred from everyday life to lessons. 
In this way, aspects that are related to subjectivity of learners during learning and appropriation are reduced. This might include the learners preferred media and modes, as well as subjectively shaped meanings, or the affective use of mobile technologies for communication and media production, and so on. However, use patterns and intentions from everyday life may be in opposition to the use and intentions of formalised school learning and other school contexts. For example, the practice of taking pictures and movies of an experiment in Austrian secondary school physics lessons (Schittelkopf 2007; Seipold 2012b) aimed to make these experiments sustainably available. The experiments had to be recorded and stored as objectively and comprehensibly as possible, because learners had to work together with these materials and at a later stage. By using photo or film, the use of the mobile phone remained very limited; it was not intended to use the devices for informal or formal discussions. Also, different modes were used successively, for example, photo and film were used for documenting the experiment, spoken word and written text aimed at adding basic information to the images. One of the results was that the spontaneous, intuitive and situational use of mobile devices was replaced by a strongly regulated use of the devices that guided learners to a reflective use of their mobile phones for documentary purposes. This result occurred as a by-product of instruction by the teacher without much space for learners to step into deconstructive learning processes.

The use of mobile technologies that is organized along school lines offers opportunities that allow equality of learners within the learning process, even if it would be desirable from the perspective of a socio-cultural ecology to integrate the everyday use of mobile technologies into the design of lessons and to carefully use the technology for school learning. For example, in relation to the use of learning platforms in connection with mobile learning, one must critically reflect if it is the use of the original functions and functionalities of mobile technologies that encourage spontaneous, situational and collaborative appropriation and meaning-making, or if the use of the devices for the recording of situations and the storing of contents on platforms stands in the centre of the learning process. Related to the latter, affective appropriation may become less important, and staggered spaces for reflection will be opened. In the regulated use of platforms and mobile technologies, all learners have the same pool of resources available that they can use to collaboratively negotiate on meanings, learn collaboratively, and build a common knowledge basis for their learning.

\section{Teachers as moderators}

Besides such aspects that are related to the compatibility of technologies or to the question of which resources of the learners' everyday life have relevance for lessons and school learning, one of the biggest challenges when opening lessons 
towards the learners' everyday life, agency and cultural practices is the changing role of teachers. Also the contradictions that become apparent when using mobile media from everyday life in school lessons make it necessary for teachers to become moderators that must mediate between the demands of school and curriculum and the interests, competencies, expertise and knowledge of learners. Teachers must classify and organise subjectively shaped aspects, objectifying them and making them available to all learners. Teachers' goals are to provide learners orientation for their learning, as well as to show them frameworks that they can use to assess relevances and to adjust their personalised and individual learning processes to demands of school. At the same time, teachers must provide a basis of information to learners that is available and comprehensible to them and that can be used for comprehending meanings and for meaning-making (or in other words: for learning) by referring to collaborative, communicative and discursive practices.

\section{Learners as revisers of structures of the learning process}

Sometimes mobile learning invisibly results in a success. In such cases it is often the learners who realise during their learning processes what is claimed within the mobile learning discussion. For example, learners relate formal and informal contexts such as school and everyday life to each other and link them together (see «Handy» project in Pachler et al. 2010; Seipold 2012b; Seipold 2011a). By doing so they construct new learning contexts. Learners manage this by situationally designing learning and learning items with the aid of different media, modes and contents from their everyday life (e.g. photos that represent leisure time activities, expertise, social contacts, fun, consumption, etc.) and school (e.g. written text, problems and solutions, question and answer formats, etc.).

With a view to such learning outcomes as described in the "Handy» project, qualifications and competences related to the use of technologies become apparent. It is primarily the resources (i.e. media, modes, contents, production methods, agency, cultural practices and knowledge, etc.) that are indicators for which concept of learning or of the relevance of resources from everyday life, everyday practices and everyday situations for school learning learners have. These resources indicate the preferred teaching and learning patterns single learners have, what they consider as being appropriate for their meaning-making, what they are making available to others (e.g. to teachers who have to evaluate and assess the learning outcomes according to categories determined by school) and more generally, how learning and school can change so that learners (with their competencies, interests, expertise, knowledge, agency and cultural practices) are taken seriously. This can be understood as a chance to revise traditional structures and to establish new ones in which learners can construct and design their own 
convergent learning spaces, contexts and revision frameworks - with and without mobile media.

\section{Closing remarks}

Mobile learning is learning with mobile technologies at first glance only. After a closer look, it becomes obvious that the mobile learning discussion is more about new or contemporary learning. Also, mobile learning covers questions that relate to other contexts such as research about teaching and learning, or teaching design, and so on. Mobile learning is even related to political dimensions when new forms of teaching, learning and schooling are discussed.

Even if there exists attempts to systematize the theoretical discussion, as well as the mobile learning practice, discrepancies and uncertainties remain. Thus, simple solutions in relation to mobile learning do not yet exist/. Assumptions of what mobile learning is and the goals of mobile learning are fluid; political claims intermix with statements about teaching and learning practice; the use of mobile technologies in school lessons do not necessarily result in innovative learning. Simply establishing mobile technologies into already existing structures of curricular learning and school lessons, as well as the mindless integration of resources and agency of learners from their everyday life, does not enhance learning. Subjectively shaped activity fade into the background in favour of objectivation and equal distribution of contents, information, infrastructure, etc. Astonishingly, in some cases, it is the learners with their agency, cultural practices and expertise in using mobile technologies who succeed in finding and establishing links between subjectively shaped appropriation and meanings on the one side and objectively framed requirements of school and curriculum on the other. By doing so, they help mobile learning obtain the innovative potential that it so often claims.

\section{References}

Alfred-Teves-Schule. 2008. «Schulwebseiten der Grund- und Hauptschule Alfred-TevesSchule, Gifhorn: Gewaltprävention - Die Medien AG der Alfred-Teves-Schule.» Accessed August 31, 2008. http://www.alfred-teves-schule.de/schulwebseiten/de/Medien-AG/ index.php.

Arnedillo-Sánchez, Inmaculada. 2008. «The mobile digital narrative tool.»In Mobile Learning 2008, ed. Inmaculada Arnedillo-Sánchez and Pedro Isaias, 77-83. Lisbon: International Association for Development of the Information Society Press.

Auer, Michael E., Arthur Edwards, and Danilo Garbi Zutin. 2011. «Online laboratories in interactive mobile learning environments.» In Work-based Mobile Learning: Concepts and cases, edited by Norbert Pachler, Christoph Pimmer, and Judith Seipold, 219-48. Oxford, Bern, Berlin, Bruxelles, Frankfurt am Main, New York, Wien: Peter Lang.

Bachmair, Ben. 2009. «Eckpunkte einer Didaktik des mobilen Lernens.» Accessed January 5, 2011. http://www.ben-bachmair.de/Eckpunkte_mobiler_Didaktik_Dez09.doc. 
Bachmair, Ben. 2009. Medienwissen für Pädagogen: Medienbildung in riskanten Erlebniswelten. Wiesbaden: VS Verlag für Sozialwissenschaften.

Bachmair, Ben. 2010. «Einleitung: Medien und Bildung im dramatischen kulturellen Wandel.» In Medienbildung in neuen Kulturräumen: Die deutschsprachige und britische Diskussion, edited by Ben Bachmair, 9-30. Wiesbaden: VS Verlag für Sozialwissenschaften.

Bachmair, Ben, ed. 2010. Medienbildung in neuen Kulturräumen: Die deutschsprachige und britische Diskussion. Wiesbaden: VS Verlag für Sozialwissenschaften.

Benedek, András. 2007. «Mobile Learning and Lifelong Knowledge Acquisition.» In Mobile Studies: Paradigms and Perspectives, edited by Kristóf Nyíri, 35-44. Communication in the 21th Century: Passagen. Accessed July 24, 2014. http://www.mta.t-mobile.mpt.bme. hu/dok/10_benedek.pdf.

Brown, Elizabeth. 2010. «Introduction to location-based mobile learning.» In Education in the Wild: Contextual and location-based mobile learning in action, eited by Elizabeth Brown, 7-9. Nottingham. Accessed July 24, 2014. http://www.Isri.nottingham.ac.uk/ejb/ preprints/ARV_Education_in_the_wild.pdf.

Cook, John. 2010. "Mobile Learner Generated Contexts. Research on the Internalization of the World of Cultural Products.» In Medienbildung in neuen Kulturräumen: Die deutschsprachige und britische Diskussion, edited by Ben Bachmair, 113-25. Wiesbaden: VS Verlag für Sozialwissenschaften.

Cook, John, Norbert Pachler, and Ben Bachmair. 2011. «Ubiquitous mobility with mobile phones: a cultural ecology for mobile learning.» E-Learning and Digital Media 8 (3, Special Issue - Media: digital, ecological, epistemological): 181-96.

Cook, John, Norbert Pachler, and Claire Bradley. 2008. «Appropriation of mobile phones for learning.» Paper given at mLearn 2008, Telford, Telford, October 2008. Accessed July 24, 2014. http://londonmobilelearning.net/downloads/Cook_Pachler_mLearn08_v3-1.ppt.

de Witt, Claudia, Sonja Ganguin, Maciej Kuszpa, and Sandro Mengel. 2011. «Mobile learning in the process of work: participation, knowledge and experience for professional development.» In Work-based Mobile Learning: Concepts and cases, edited by Norbert Pachler, Christoph Pimmer, and Judith Seipold, 147-71. Oxford, Bern, Berlin, Bruxelles, Frankfurt am Main, New York, Wien: Peter Lang.

del Mundo, Marjorie. 2009. «M-Learning: From ETEC 510.» Accessed January 5, 2011. http:// delmundo.ca/wp-content/uploads/2009/02/m-learning-etec-510.pdf.

Engeström, Yrjö. 2001. «Expansive learning at work: Toward an activity theoretical reconceptualisation.» Journal of Education and Work 14 (1): 133-56.

Engeström, Yrjö. 2005. «Knotworking to Create Collaborative Intentionality Capital in Fluid Organizational Fields.» Advances in Interdisciplinary Studies of Work Teams (11): 30736. doi:10.1016/S1572-0977(05)11011-5.

Ernst, Heike. 2008. Mobiles Lernen in der Praxis: Handys als Lernmedium im Unterricht. Boizenburg: Verlag Werner Hülsbusch.

Glotz, Peter, Stefan Bertschi, Chris Locke, and Henning Thies, eds. 2006. Daumenkultur: Das Mobiltelefon in der Gesellschaft. Bielefeld: transcript Verlag. Accessed July 24, 2014. http://www.gbv.de/dms/bsz/toc/bsz25067100xinh.pdf.

Joint Information Systems Committee (JISC). 2008. «Podcast: Mobile education is the way of the future...: Interview with John Traxler.» Accessed July 24, 2014. http://www.jisc. ac.uk/news/stories/2008/01/podcast25johntraxler.aspx. 
Kukulska-Hulme, Agnes. 2005. «Introduction.» In Mobile Learning: A Handbook for Educators and Trainers, edited by Agnes Kukulska-Hulme and John Traxler. New Edition, 1-6. The Open and Flexible Learning Series. London, New York: Routledge.

Kukulska-Hulme, Agnes, and John Traxler. 2005. "Mobile teaching and learning.»In Kukulska-Hulme and Traxler, Mobile Learning: A Handbook for Educators and Trainers, 25-44.

Laurillard, Diana. 2002. Rethinking University Teaching: A conversational framework for the effective use of learning technologies. $2^{\text {nd }}$ ed. London: RoutledgeFalmer.

Laurillard, Diana. 2007. «Pedagogical forms for mobile learning: framing research question.» In Mobile learning - towards a research agenda, edited by Norbert Pachler, 153-75. Occasional Papers in Work-based Learning 1. London: WLE Centre. Accessed July 24, 2014. http://eprints.ioe.ac.uk/5402/1/mobilelearning_pachler_2007.pdf.

Lave, Jean, and Etienne Wenger. 1991. Situated Learning: Legitimate peripheral participation. Learning in Doing: Social, Cognitive, and Computational Perspectives. Cambridge, UK: Cambridge University Press.

Luckin, Rosemary, Wilma Clark, Fred Garnett, Andrew Whitworth, Jon Akass, John Cook, Peter Day, Nigel Ecclesfield, Tom Hamilton, and J. Robertson. 2010. «Learner Generated Contexts: a framework to support the effective use of technology to support learning.» In Web 2.0-based e-learning: applying social informatics for tertiary teaching, edited by M. J. W. Lee and C. Loughlin, 70-84. Hershey, PA: IGI Global. Accessed July 24, 2014. http://knowledgeillusion.files.wordpress.com/2012/03/book chapterluckin2009learnergeneratedcontexts.pdf.

medienbewusst.de - kinder. medien. kompetenz. 2009. "Alfred-Teves-Schule- Aktiv gegen Gewaltvideos.» Accessed July 24, 2014. http://www.medienbewusst.de/handy/20090111/ alfred-teves-schule-aktiv-gegen-gewaltvideos.html.

Medienpädagogischer Forschungsverbund Südwest (mpfs). 2013. «Handys, Smartphones, Apps.» Infoset Medienkompetenz: 10 Fragen - 10 Antworten. Accessed July 24, 2014. http://www.mpfs.de/fileadmin/Infoset_neu/Infoset_Handy.pdf.

Naismith, Laura, Peter Lonsdale, Giasemi Vavoula, and Mike Sharples. 2004. Literature Review in Mobile Technologies and Learning. Futurelab Report 11. Bristol: Futurelab. Accessed July 24, 2014. http://archive.futurelab.org.uk/resources/documents/lit_ reviews/Mobile_Review.pdf.

Pachler, Norbert. 2010. «The Socio-Cultural Ecological Approach to Mobile Learning: An Overview.» In Medienbildung in neuen Kulturräumen: Die deutschsprachige und britische Diskussion, edited by Ben Bachmair, 153-67. Wiesbaden: VS Verlag für Sozialwissenschaften.

Pachler, Norbert, Ben Bachmair, and John Cook. 2010. Mobile learning: structures, agency, practices. With the assistance of G. Kress, J. Seipold, E. Adami and K. Rummler. New York: Springer. Accessed July 24, 2014. http://www.springerlink.com/content/v65pt8/.

Schittelkopf, Eduard. 2007. «Kurs: Spannung und Stromstärke.» Accessed August 24, 2007. http://www.mobileclassroom.at/moodle/course/view.php?id=23.

Seipold, Judith. 2011a. A Critical Perspective on Mobile Learning: Results of a heuristic analysis of the scientific process and a hermeneutic analysis of mobile learning practice. «Mobile learning: Crossing boundaries in convergent environments〉 Conference, Bremen. 
Seipold, Judith. 2011b. Mobile Learning: Potential and controversies embodied in a young scientific field and arising consequences for future research and practice with view to social, networked and (informal) learning. SoMobNet Roundtable, London, November 21. Accessed July 24, 2014. http://www.slideshare.net/KlausR/judith-seipold -somobnet20111121 areduced.

Seipold, Judith. 2011c. «Planung von Mobilem Lernen im Unterricht: Hinweise und Beispiele für die Praxis.» Computer + Unterricht - Lernen und lehren mit digitalen Medien 84 (Spezial Lernen. Themenschwerpunkt betreut von Johannes Fromme, Ralf Biermann u. Alexander Unger): 49-51.

Seipold, Judith. 2012a. Mobile Learning: Potential and controversy embodied in a young scientific field, and arising consequences for future research and practice. Educational Media Ecologies: International Perspectives, Paderborn, March 27.

Seipold, Judith. 2012b. Mobiles Lernen: Analyse des Wissenschaftsprozesses der britischen und deutschsprachigen medienpädagogischen und erziehungswissenschaftlichen Mobile Learning-Diskussion. Kassel: Universität Kassel. Accessed July 24, 2014. http:// nbn-resolving.de/urn:nbn:de:hebis:34-2012121242324.

Seipold, Judith. 2013. "Mobiles Lernen: Systematik, Theorien und Praxis eines noch jungen Forschungsfeldes.» In Mobile Learning: Potentiale, Einsatzszenarien und Perspektiven des Lernens mit mobilen Endgeräten, edited by Claudia de Witt, Almut Sieber, and Claudia de Witt, 27-54. Wiesbaden: Springer VS. Accessed July 24, 2014. http://link. springer.com/chapter/10.1007/978-3-531-19484-4_3.

Sharples, Mike. 2007. "Mobile Learning.» Accessed July 24, 2014. http://www.noe -kaleidoscope.org/pub/network/communities/sig/activity.php?wp=107.

Sharples, Mike, Inmaculada Arnedillo-Sánchez, Marcelo Milrad, and Giasemi Vavoula. 2007. «Mobile Learning: Small devices, Big issues.» Accessed January 5, 2011. http://www .Isri.nottingham.ac.uk/msh/Papers/KAL_Legacy_Mobile_Learning.pdf.

Sharples, Mike, Josie Taylor, and Giasemi Vavoula. 2005. "Towards a Theory of Mobile Learning.» Accessed July 24, 2014. http://www.eee.bham.ac.uk/sharplem/Papers/ Towards\%20a\%20theory\%20of\%20mobile\%20learning.pdf.

Sharples, Mike, Josie Taylor, and Giasemi Vavoula. 2010. «A Theory of Learning for the Mobile Age. Learning through Conversation and Exploration Across Contexts.» In Medienbildung in neuen Kulturräumen: Die deutschsprachige und britische Diskussion, edited by Ben Bachmair, 87-99. Wiesbaden: VS Verlag für Sozialwissenschaften.

The Learner Generated Contexts Group. 2008. «Learner Generated Contexts - Working Definition.» Accessed July 24, 2014. http://learnergeneratedcontexts.pbworks.com/ Working+Definition.

Traxler, John. 2005. «Defining Mobile Learning.» In IADIS International Conference Mobile Learning 2005, edited by Pedro Isaías, Carmel Borg, Piet Kommers, and Philip Bonanno, 261-66. Accessed January 5, 2011. http://www.iadis.net/dl/final_uploads/200506C018 .pdf.

Traxler, John. 2009. «Learning in a Mobile Age.» International Journal of Mobile and Blended Learning 1 (1): 1-12. Accessed July 24, 2014. https://www.academia.edu/171500/ Learning_in_a_Mobile_Age.

Traxler, John. 2010. «Doing it Right! Methods, Ethics and Hearing the Learner Voice.» Online Beitrag bei ELESIG \& HEEthicsWeb2.0 joint event. Accessed July 24, 2014. http://wlv. academia.edu/JohnTraxler/Talks/15764/Doing_it_Right_Methods_Ethics_and_Hearing_ the_Learner_Voice. 
Vygotsky, Lev. (1930) 1978. Mind in Society: The Development of Higher Psychological Processes. Edited by Michael Cole. Cambridge, MA: Harvard University Press.

Wishart, Jocelyn. 2010. «The need to plan ahead for social and ethical challenges in contextual and location-based learning.» In Education in the Wild: Contextual and location-based mobile learning in action, edited by Elizabeth Brown, 17-19. Nottingham. Accessed July 24, 2014. http://www.Isri.nottingham.ac.uk/ejb/preprints/ARV_Education_in_the_wild.pdf. Wishart, Jocelyn. 2011. «Ethical concerns relevant to researching work based mobile learning.» In Work-based Mobile Learning: Concepts and cases, edited by Norbert Pachler, Christoph Pimmer, and Judith Seipold, 305-331. Oxford, Bern, Berlin, Bruxelles, Frankfurt am Main, New York, Wien: Peter Lang. 